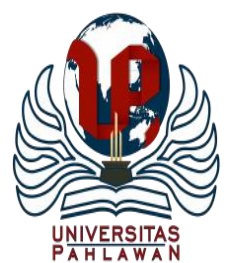

Edukatif : Jurnal Ilmu Pendidikan Volume 3 Nomor 5 Tahun 2021 Halm 2586 - 2593

EDUKATIF: JURNAL ILMU PENDIDIKAN

Research \& Learning in Education

https://edukatif.org/index.php/edukatif/index

\title{
Analisis Pelaksanaan Pembelajaran Online dalam Masa Pandemi Covid-19 berdasarkan Persepsi Guru Sekolah Menengah Kejuruan
}

\author{
Lusiani $^{\text {凶 }}$ \\ Akademi Maritim Nusantara, Indonesia \\ E-mail : $\underline{\text { anilusi0287@gmail.com }}$
}

\begin{abstract}
Abstrak
Tujuan yang akan dicapai yakni menganalisis pelaksanaan pembelajaran online dalam masa pandemi covid-19 berdasarkan persepsi guru Sekolah Menengah Kejuruan. Kajian ini menggunakan metode penelitian kualitatif dengan pendekatan deskriptif. Penelitian dilakukan bulan Januari 2021 di SMK Bina Bhakti Cilacap secara online. Subjek kajian ini yakni guru di SMK Bina Bhakti yang melaksanakan pembelajaran online dalam masa pandemi covid-19. Wawancara dilakukan pada 10 orang guru yang mengajar di SMK Bina Bhakti. Simpulan penelitian ini yakni pembelajaran online dapat dilaksanakan dalam masa pandemi covid-19, namun memiliki beberapa kelebihan dan kekurangan. Adapun kelebihan baiknya terus dipertahankan bahkan ditingkatkan sedangkan kekurangan dapat diatasi serta diantisipasi. Beberapa hal dapat dilakukan untuk mempersiapkan pelaksanaan pembelajaran online dengan baik, antara lain: pelatihan penggunaan beragam media pembelajaran online baik bagi guru maupun siswa, pemberian subsidi kouta dengan mempertimbangkan faktor ekonomi, domisili peserta didik, dukungan orang tua dalam memberikan fasilitas belajar siswa saat di rumah, pengalihfungsian dana alokasi media pembelajaran dikelas menjadi online.
\end{abstract}

Kata Kunci: Analisis, Pembelajaran Online, Persepsi

\section{Abstract}

The goal to be achieved is to analyze the implementation of online learning during the COVID-19 pandemic based on the perceptions of Vocational High School teachers. This study uses a qualitative research method with a descriptive approach. The research was conducted in January 2021 at SMK Bina Bhakti Cilacap online. The subject of this study is a teacher at Bina Bhakti Vocational School who carries out online learning during the COVID-19 pandemic. Interviews were conducted with 10 teachers who teach at SMK Bina Bhakti. The conclusion of this study is that online learning can be carried out during the COVID-19 pandemic, but it has several advantages and disadvantages. The advantages are good to continue to be maintained and even improved while the shortcomings can be overcome and anticipated. Several things can be done to prepare for the implementation of online learning properly, including training on the use of various online learning media for both teachers and students, providing quota subsidies by considering economic factors, student domicile, parental support in providing student learning facilities at home., the transfer of the allocation of funds for learning media in the classroom to be online.

Keywords: Analysis, Online Learning, Perception

Copyright (c) 2021 Lusiani

$\triangle$ Corresponding author:

Email : anilusi0287@gmail.com $\quad$ ISSN 2656-8063 (Media Cetak)

DOI : https://doi.org/10.31004/edukatif.v3i5.920 ISSN 2656-8071 (Media Online)

Edukatif : Jurnal Ilmu Pendidikan Vol 3 No 5 Tahun 2021 p-ISSN 2656-8063 e-ISSN 2656-8071 


\section{PENDAHULUAN}

Saat pandemi covid-19 beberapa bidang terdampak salah satunya yakni pendidikan. Perguruan Tinggi merupakan salah satu bidang yang perlu menyesuaikan adanya pandemi dengan perubhan sistem kegiatan belajar mengajar langsung lalu menjadi online. Beragam media dimanfaatkan pada kegiatan belajar mengajar online. Guru serta siswa harus bisa beradaptasi serta membiasakan diri memanfaatkan teknologi informasi di beragam media belajar online dengan tujuan penjaminan kualitas hasil belajar siswa.

Aktivitas belajar mengajar daring yang dilaksanakan dengan tidak bertatap muka langsung, namun dengan platform yang ada. Beragam tampilan materi pelajaran disampaikan melalui daring, komunikasi dan tes pun dilaksanakan melalui daring. (Chrismawati et al., 2021)

Penggunaan internet dalam sistem pembelajaran jarak jauh menggunakan aktivitas pembelajaran elektronik (E- Learning). Pembelajaran Daring yakni program penyelenggaraan kelas belajar dalam jaringan yang mencakup kelompok target secara masif serta luas. Aktivitas belajar mengajar ini dilaksanakan serta dapat diikuti gratis ataupun bertarif dengan maksud memberikan layanan kegiatan belajar mengajar bermutu secara dalam jaringan dengan sifat masif serta terbuka dalam mencakup audiens lebih banyak serta luas. (Mulyadi, 2020)

Pembelajaran daring efektif mengatasi kegiatan belajar mengajar yang memungkinan pendidik serta peserta didik berinteraksi melalui kelas virtual yang memiliki akses tidak terbatas ruang serta waktu. Kegiatan belajar mengajar daring bisa menjadikan mahasiswa belajar mandiri serta meningkatkan motivasi. Kekurangan pembelajaran daring yakni peserta didik tidak terkontrol dengan baik saat proses pembelajaran. Sinyal internet yang tidak stabil serta tingginya biaya kuota merupakan tantangan tersendiri. Namun pembelajaran daring menekan penyebaran Covid-19 di perguruan tinggi. (Sadikin \& Hamidah, 2020)

Perkembangan teknologi memberikan peluang pembelajaran daring dilaksanakan dengan baik. Komunikasi 2 arah antara pendidik serta peserta didik akan semakin baik sebab tersedia brbagai pilihan media komunikasi. Sehingga membuka peluang pendidik menyampaikan materi secara langsung melalui video conference. Peserta didik bisa mengulang video tersebut beberapa kali sebagai materi pembelajaran agar lebih dapat memahami. Kunci efektivitas sistem pembelajaran daring yakni pendidik yang harus tetap kreatif dalam menyampaikan materi secara menyenangkan serta mudah dipahami sehingga peserta didik tidak jenuh serta tetap produktif di rumah. (Napsawati, 2020)

Persepsi merupakan tahapan mental yang rumit serta melingkupi beragam aktivitas dalam mengklasifikasikan stimulus yang diterima hingga memperoleh respon dalam meresapi stimulus tersebut. pembentukan persepsi yakni melewati beragam aktivitas, antara lain proses fisik, fisiologis (pengiriman hasil penginderaan menuju otak dengan saraf sensoris) serta psikologis (ingatan, perhatian, pemrosesan informasi dalam otak). (Mardijono, 2008)

Media kegiatan belajar mengajar online merupakan media lengkap dengan alat pengendali yang bisa dimanfaatkan pengguna yang bisa mengontrol dan memberikan akses sesuatu yang dibutuhkan. (Arnesti \& Hamid, 2015).

Salah satu faktor tercapainya tujuan pembelajaran yakni bergunanya media kegiatan belajar mengajar menjadi wadah penyampaian pesan kegiatan belajar mengajar dari sumber pembelajaran ataupun pada penerimanya yang berhubungan dengan peran guru. Kompetensi pendidik dalam memberikan teori pada peserta didik adalah hal wajib hingga bisa digunakan bahan pertimbangan dalam pengembangan serta tindak lanjut penggunaan model maupun media yang efektif dan efisien. Kompetensi pendidik saat menciptakan media pembelajaran berbasis TIK belum maksimal sehingga diperlukan peningkatan. (Aini, 2019)

Penggunaan multimedia secara tepat oleh pendidik dalam pembelajaran, dapat memberikan tambahan wawasan yang baik pada peserta didik. Multimedia dapat melengkapi serta mendukung materi yang diberikan saat proses pembelajaran yang diperoleh peserta didik saat di kelas. Multimedia merupakan program 
perbaikan apabila peserta didik terkendala dalam menyerap materi yang disampaikan guru dalam kelas diberikan peluang memanfaatkan multimedia yang didesain khusus bertujuan supaya peserta didik lebih mudah menyerap hal yang diberikan guru di kelas. (Wibawa et al., 2019)

Pelaksanaan pembelajaran daring yang dilakukan pendidik dengan pemanfaatan smartphone, laptop serta jaringan internet saat proses pembelajaran hingga proses penyampaian materi pada peserta didik tetap berlangsung. Pengalaman guru saat pembelajaran daring memiliki kelebihan antara lain: 1) pembelajaran lebih efektif, efisien; 2) peserta didik lebih leluasa mempelajari materi secara individu; 3) memperluas jangkauan pembelajaran; 4) pembelajaran secara mandiri. Sedangkan kekurangannya 1) keterbatasan sarana prasarana; 2) akses internet yang tidak merata pada masing-masing tempat; 3) fasilitas yang dimiliki peserta didik tidak merata. Manfaat pembelajaran daring bagi pendidik yakni peningkatan kompetensi penggunaan teknologi dalam pembelajaran. (Lindawati \& Rahman, 2020)

Adaptasi pendidik saat pelaksanaan pembelajaran daring antara lain memahami definisi pembelajaran daring. Pendidik berusaha mencari informasi pembelajaran daring menggunakan teknologi internet sejenis google, youtube, diskusi dengan rekan sejawat. Terbatasnya waktu seorang pendidik saat mempelajari pembelajaran daring menjadikannya banyak mendapat kendala, namun dapat diatasi melalui dukungan pihak lain sejenis media internet, rekan sejawat, media cetak. Adanya pihak sekolah dalam memberikan dukungan pelaksanaan pembelajaran daring dapat menjadi salah satu motivasi pendidik dalam beradaptasi dengan model pembelajaran daring saat pandemi Covid-19. (Lindawati \& Rahman, 2020)

Guru memiliki tanggung jawab membentuk kepribadian siswa dengan hasil belajar yang optimal dengan pesan yang diberikan kepada siswa, hingga peserta didik mampu menerima pesan yang masuk serta mencernanya sehingga ada hubungan timbal balik. (Handayani et al., 2021)

Pembelajaran online memberikan kemudahan mentransfer informasi dalam berbagai situasi serta kondisi yang didukung platform beragam mulai dari diskusi hingga tatap muka virtual. Evaluasi serta penyesuaian kondisi setempat perlu dilaksanakan, dengan memperhatikan kemampuan orang tua menyediakan fasilitas pembelajaran online yang tidak sama. Kunci dalam hal ini yakni kemampuan peserta didik belajar dengan maksimal saat pandemi. (Herliandry et al., 2020)

Solusi pelaksanaan pembelajaran saat pandemi agar menekan penyebaran virus yakni penerapan pembelajaran daring. Pembelajaran daring memberikan keleluasaan pada peserta didik memperoleh informasi luas melalui sumber beragam jika kondisi kegiatan pembelajaran berlangsung dengan aktif, kondusif serta terlaksana dengan efektif. Dibutuhkan upaya komprehensif antara pendidik dan peserta didik. Pendidik wajib bisa memberikan pembelajaran daring berkualitas serta pendidik harus bisa mengikuti kegiatan belajar mengajar secara baik. Faktor-faktor penghambat dapat diminimilasasi mulai akses internet, waktu yang terbatas serta kualitas pembelajaran dikondisikan supaya tujuan pembelajaran daring tercapai. (Firdaus, 2020)

Supaya pembelajaran daring lebih efektif, diperlukan persiapan sarana teknologi informasi pendukung pembelajaran daring (Perguruan Tinggi, Pemerintah) dengan kondisi peserta didik serta pendidik dilatih menggunakan sarana teknologi informasi hingga memberikan kemudahan guru serta siswa berinteraksi saat proses pembelajaran berbasis teknologi informasi. Bantuan paket data bagi peserta didik yang kurang mampu bisa menjadi solusi dari tingginya biaya pembelajaran daring. (Damayanthi, 2020)

Aktivitas belajar mengajar matematika dapat lebih efektif selanjutnya guru melakukan beberapa masukan dari siswa, yaitu (1) aktivitas belajar mengajar dengan video call; (2) materi belajar mengajar diberikan ringkas; (3) meminimalisasi materi yang dikirim berbentuk video kapasitas tinggi agar hemat kuota; (4) materi terpilih dalam video menggunakan bahasa yang mudah dimengerti; (5) pemberian materi sebelum penugasan; (6) memberikan soal variatif serta berbagai jenis masing-masing murid; (7) memberikan tugas beserta cara kerja; (8) pemberian tugas sesuai jadwal; (9) peserta didik diingatkan terhadap pemberian tugas; (10) meminimalisasi tugas.(Mustakim, 2020) 
Faktor yang mendukung kegiatan belajar mengajar daring antara lain handphone, kuota, jaringan internet stabil, beberapa hal tersebut digunakan pendidik secara maksimal untuk mengontrol perkembangan siswa saat kegiatan belajar mengajar daring. Terdapat hambatan yang dialami pendidik saat kegiatan belajar mengajar, yakni peserta didik belum menyeluruh mempunyai handphone serta sebagian besar orang tua sibuk bekerja. Orang tua merupakan individu yang diutamakan saat kegiatan belajar mengajar daring, sebab orang tua secara langsung ikut memberikan bimbingan serta pengawasan terhadap peserta didik dalam saat kegiatan belajar mengajar. Motivasi yang diberikan sangat bermanfaat bagi peserta didik, walaupun belajar dari rumah. (Putria et al., 2020)

Berdasarkan beberapa penjelasan yang disampaikan peneliti lain, secara garis besar dapat dirangkum beberapa hal terkait pembelajaran online saat pandemi coivid-19 yakni: Pengalaman guru saat pembelajaran daring memiliki kelebihan antara lain: 1) pembelajaran lebih efektif, efisien; 2) peserta didik lebih leluasa mempelajari materi secara individu; 3) memperluas jangkauan pembelajaran; 4) pembelajaran secara mandiri.

Sedangkan kekurangannya 1) keterbatasan sarana prasarana; 2) akses internet yang tidak merata pada masing-masing tempat; 3) fasilitas yang dimiliki peserta didik tidak merata. Berbagai kendala dapat diatasi melalui dukungan pihak lain sejenis media internet, rekan sejawat, media cetak. Terdapat kendala yang dihadapi pendidik saat kegiatan belajar mengajar, yakni peserta didik belum menyeluruh mempunyai handphone serta sebagian besar orang tua sibuk bekerja. Orang tua merupakan individu yang diutamakan saat pembelajaran online, sebab orang tua secara langsung ikut memberikan bimbingan serta pengawasan terhadap peserta didik dalam saat kegiatan belajar mengajar. Solusi beberapa kendala yakni diperlukan persiapan sarana teknologi informasi pendukung pembelajaran daring (Perguruan Tinggi, Pemerintah) dengan kondisi peserta didik serta pendidik dilatih menggunakan sarana teknologi informasi hingga memberikan kemudahan guru serta siswa berinteraksi saat pembelajaran berbasis teknologi informasi. Bantuan paket data bagi peserta didik yang kurang mampu bisa menjadi solusi dari tingginya biaya pembelajaran daring.

Sedangkan hal yang akan dibahas peneliti adalah terkait persepsi atau pendapat dari sudut pandang pendidik atau guru yang terlibat sebagai fasilitator dalam pelaksanaan pembelajaran online. Tujuan penelitian ini yakni melakukan analisis terhadap pelaksanaan pembelajaran online dalam masa pandemi covid-19 ditinjau dari sudut pandang pendidik. Pendidik harus mampu beradaptasi terhadap pembelajaran berbasis teknologi, sedangkan lingkungan belajar lain seperti pihak sekolah, keluarga (orang tua) ikut memberikan andil dalam tercapainya tujuan pembelajaran jarak jauh yang membutuhkan kerja sama berbagai pihak.

\section{METODE PENELITIAN}

Kajian ini menggunakan metode penelitian kualitatif melalui pendekatan deskriptif. Tujuan kajian yakni menganalisis pelaksanaan pembelajaran online dalam masa pandemi covid-19 berdasarkan persepsi guru Sekolah Menengah Kejuruan serta mendeskripsikannya berbentuk kalimat naratif. Waktu penelitian dilakukan pada bulan Januari 2021 berlokasi di SMK Bina Bhakti Cilacap secara online. Subjek pada kajian ini yakni guru di SMK Bina Bhakti yang melaksanakan pembelajaran online dalam masa pandemi covid-19. Observasi dilakukan melalui media whatsapp dengan pengamatan terhadap laporan kegiatan belajar yang disampaikan Kepala Sekolah selama pelaksanaan pembelajaran online. Wawancara dilakukan pada 10 orang guru yang mengajar di SMK Bina Bhakti yang berinisial DA pengampu mapel Produktif akuntansi, NR pengampu mapel Matematika, WR pengampu mapel Bahasa Inggris dan simulasi komunikasi digital, RPA pengampu makul PPKN, DC pengampu makul produktif OTPKP, AA pengampu mapel Pendidikan Agama Islam, NF pengampu mapel Produktif otomatisasi dan tatakelola perkantoran, WW pengampu mapel administrasi umum, SNY pengampu mapel farmakognosi dan farmakologi, DNF pengampu mapel bahasa Inggris. Wawancara dilakukan untuk mengkonfirmasi dan menggali informasi lebih detail terkait pelaksanaan pembelajaran online yang dilakukan oleh guru. Wawancara disusun dalam 2 bentuk yakni secara verbal melalui google meet dan secara tertulis yakni melalui google form. 
2590 Analisis Pelaksanaan Pembelajaran Online dalam Masa Pandemi Covid-19 berdasarkan Persepsi Guru Sekolah Menengah Kejuruan - Lusiani

DOI: https://doi.org/10.31004/edukatif.v3i5.920

\section{HASIL DAN PEMBAHASAN PENELITIAN}

Observasi serta wawancara yang dilaksanakan melalui online. Observasi dilakukan melalui media whatsapp dengan pengamatan terhadap laporan kegiatan belajar yang disampaikan Kepala Sekolah selama pelaksanaan pembelajaran online. Wawancara disusun dalam 2 bentuk yakni secara verbal melalui google meet dengan link https://meet.google.com/xkw-aotb-hgc?=1 dan secara tertulis yakni melalui google form dengan link https://bit.ly/kuesionerpersepsiguru dengan pertanyaan pilihan pelaksanaan pembelajaran online, offline, atau keduanya, selain itu terdapat pertanyaan yakni bagaimana persepsi Bapak/Ibu Guru terkait media pembelajaran yang efektif dan efisien dalam pelaksanaan pembelajaran online yang digunakan pada masa pandemi Covid-19?, jawaban atas pertanyaan ini berbentuk naratif atau deskripsi. Adapun proses pengambilan data bersamaan dengan kegiatan pengabdian kepada masyarakat yang diselenggarakan peneliti di lokasi SMK Bina Bhakti Cilacap. Peserta dalam meeting berjumlah 14 orang, 1 peneliti, 2 rekan kerja dengan bidang ilmu ekonomi dan matematika, serta 1 pihak operator sekolah, dan 10 guru mata pelajaran lainnya.

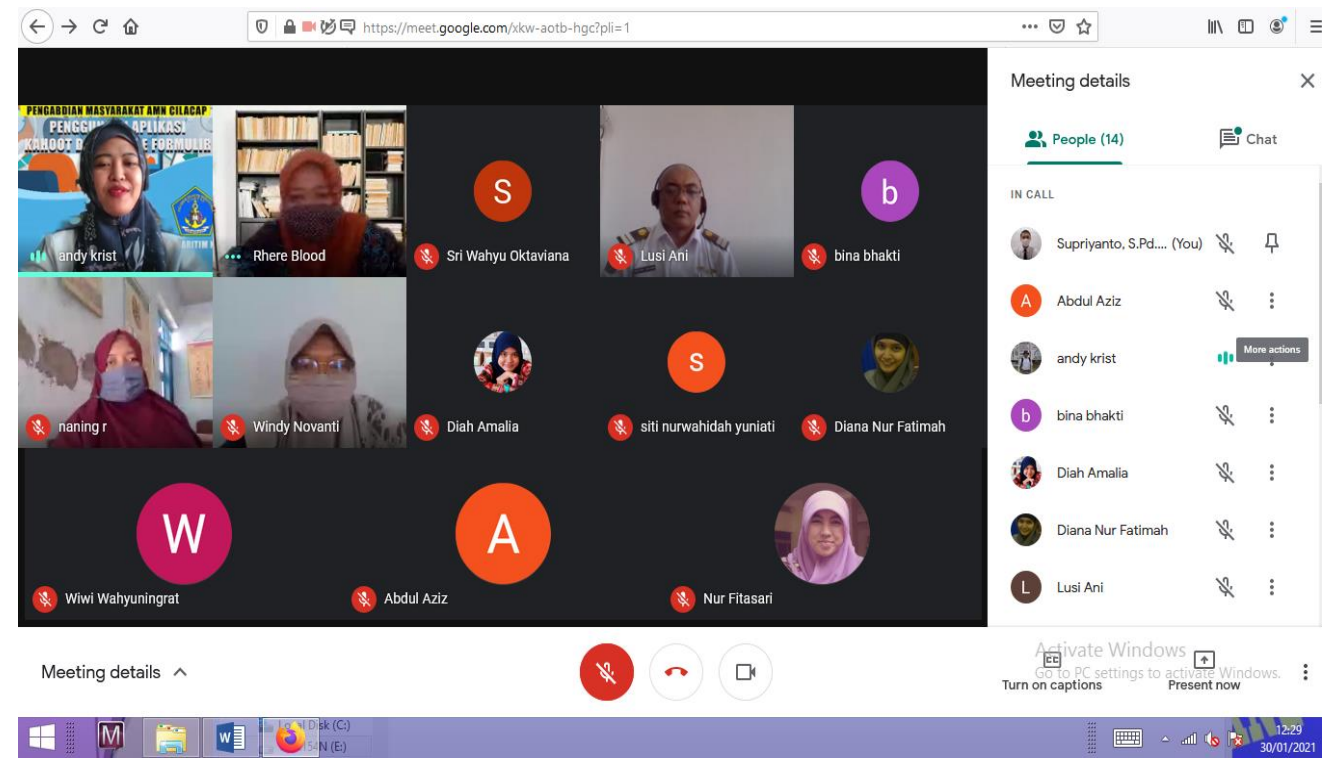

Gambar 1. Wawancara secara verbal melalui google meet

Hasil penelitian yang diperoleh melalui wawancara secara tertulis menggunakan google form dirangkum serta dapat dideskripsikan melalui tabel di bawah ini:

Tabel 1

Deskripsi Persepsi Guru

\begin{tabular}{ccl}
\hline No & Guru & \multicolumn{1}{c}{ Deskripsi Persepsi } \\
\hline 1 & DA & $\begin{array}{l}\text { Media online bagus akan tetapi bagi siswa yang kondisi menengah, hal ini menjadi } \\
\text { kurang efektif dan efisien karena biasanya kendala memori hp dan keuangan }\end{array}$ \\
\hline 2 & NR & $\begin{array}{l}\text { Media online di sekolah kami masih terbatas penerapannya karena keterbatasan } \\
\text { fasilitas yang dimiliki siswa }\end{array}$ \\
\hline 3 & WR & $\begin{array}{l}\text { Daring dan luring lebih efektif ketimbang hanya daring saja. hal ini dikarenakan } \\
\text { kondisi lingkungan masing-masing siswa. }\end{array}$ \\
\hline 4 & RPA & $\begin{array}{l}\text { Sangat diperlukan media yang efektif, mengingat pembelajaran dengan jarak jauh } \\
\text { sangat banyak kendalanya. }\end{array}$ \\
\hline 5 & DC & $\begin{array}{l}\text { Media pembelajaran interaktif masa pandemi sangat variatif dan bisa digunakan. } \\
\text { Menurut saya, Media pembelajaran online saat pandemi ada kekurangan dan } \\
\text { kelebihan. Bagi guru-guru bisa meningkatkan metode belajar yang tidak bosan dan } \\
\text { bisa digunakan meski tidak pandemi. Kendalanya untuk siswa kurang efektif dan } \\
\text { banyak anak yang kendala misal kuota. Memori hp penuh sehingga tidak bisa instal. }\end{array}$ \\
\hline 6 & AA & Pembelajaran online untuk guru efektif akan tetapi jika untuk siswa kalangan \\
\hline
\end{tabular}




\begin{tabular}{ccl}
\hline & & menengah ke bawah biasanya tidak efisien karena kendala oleh kuota dan hp \\
\hline 7 & NF & $\begin{array}{l}\text { Media yang efisien sebenarnya sangat banyak, kita harus bisa menyesuaikan sesuai } \\
\text { dengan kebutuhan dan keadaan siswa yang tidak semua berdomisili di kota dan tidak } \\
\text { semua memiliki ponsel pintar. }\end{array}$ \\
\hline 8 & WW & Memudahkan dalam penyampaian materi ajar. \\
\hline 10 & SNY & $\begin{array}{l}\text { Media yang digunakan harus mudah dan murah. Melihat kondisi latar belakang } \\
\text { siswa yang berbeda beda dan faktor ekonomi perlu dipertimbangkan }\end{array}$ \\
\hline & DNF & $\begin{array}{l}\text { Media yang mudah diakses, dioperasionalkan, yang dapat menggantikan tatap muka. } \\
\text { Menurut saya, semua media pembelajaran dapat digunakan secara efektif dan efisein } \\
\text { dalam masa pandemi sekarang ini tergantung dari orang yang menggunakannya. } \\
\text { Karena jika yang masih awam dan masih asing dengan aplikasi media tersebut maka } \\
\text { akan kesulitan dalam menggunakanya. Terlebih lagi jika terkendala dengan koneksi. }\end{array}$ \\
\hline
\end{tabular}

Berdasarkan tabel tersebut, dapat dideskripsikan beberapa hal antara lain: pembelajaran pada SMK bina Bhakti Cilacap dapat dilaksanakan secara online dalam masa pandemi covid-19, namun memiliki keterbatasan dalam penerapannya. Sebagian besar guru memiliki persepsi bahwa pembelajaran dapat menggunakan media online yang variatif, efektif, efisien, interaktif, mudah diakses serta dioperasionalkan. Media online dipandang bagus atau baik namun memiliki beberapa hal yang perlu diperhatikan dan dipertimbangkan yakni memori hp, kuota, domisili tidak menyeluruh di kota, keterbatasan fasilitas yang dimiliki siswa (tidak semua siswa memiliki ponsel pintar), kondisi lingkungan, kondisi latar belakang siswa yang berbeda, serta faktor ekonomi (keuangan). Sedangkan persepsi guru dari segi lain terkait pelaksanaan pembelajaran online yakni pembelajaran dilaksanakan baiknya merupakan kombinasi antara daring (online) dan luring, dalam pembelajaran online guru bisa meningkatkan metode belajar yang tidak bosan dan bisa digunakan meski tidak pandemi, memudahkan dalam penyampaian materi ajar, kesulitan menggunakan media online terjadi apabila guru merasa masih awam dan asing dengan aplikasi media online.

Hal tersebut dapat memberikan gambaran bahwa pembelajaran online dapat dilaksanakan dalam masa pandemi covid-19, namun memiliki beberapa kelebihan dan kekurangan. Adapun kelebihan baiknya terus dipertahankan bahkan ditingkatkan sedangkan kekurangan dapat diatasi serta diantisipasi. Beberapa hal dapat dilakukan untuk mempersiapkan pelaksanaan pembelajaran online dengan baik, antara lain: pelatihan penggunaan beragam media pembelajaran online baik bagi guru maupun siswa, pemberian subsidi kouta dengan mempertimbangkan faktor ekonomi, domisili peserta didik, dukungan orang tua dalam memberikan fasilitas belajar siswa saat di rumah, pengalihfungsian dana alokasi media pembelajaran dikelas menjadi online.

Sesuai yang disampaikan peneliti lain yakni Pengalaman guru saat pembelajaran daring memiliki kelebihan antara lain: 1) pembelajaran lebih efektif, efisien; 2) peserta didik lebih leluasa mempelajari materi secara individu; 3) memperluas jangkauan pembelajaran; 4) pembelajaran secara mandiri. Sedangkan kekurangannya 1) keterbatasan sarana prasarana; 2) akses internet yang tidak merata pada masing-masing tempat; 3) fasilitas yang dimiliki peserta didik tidak merata. (Lindawati \& Rahman, 2020). Berbagai kendala dapat diatasi melalui dukungan pihak lain sejenis media internet, rekan sejawat, media cetak. Adanya pihak sekolah dalam memberikan dukungan pelaksanaan pembelajaran daring dapat menjadi salah satu motivasi pendidik dalam beradaptasi dengan model pembelajaran daring saat pandemi Covid-19. (Lindawati \& Rahman, 2020). Dibutuhkan upaya komprehensif antara pendidik dan peserta didik. Faktor-faktor penghambat dapat diminimilasasi mulai akses internet, waktu yang terbatas serta kualitas pembelajaran dikondisikan supaya tujuan pembelajaran daring tercapai. (Firdaus, 2020). Diperlukan persiapan sarana teknologi informasi pendukung pembelajaran daring (Perguruan Tinggi, Pemerintah) dengan kondisi peserta didik serta pendidik dilatih menggunakan sarana teknologi informasi hingga memberikan kemudahan guru serta siswa berinteraksi saat pembelajaran berbasis teknologi informasi. Bantuan paket data bagi peserta didik yang kurang mampu bisa menjadi solusi dari tingginya biaya pembelajaran daring. (Damayanthi, 2020). Terdapat kendala yang 
dihadapi pendidik saat kegiatan belajar mengajar, yakni peserta didik belum menyeluruh mempunyai handphone serta sebagian besar orang tua sibuk bekerja. Orang tua merupakan individu yang diutamakan saat pembelajaran online, sebab orang tua secara langsung ikut memberikan bimbingan serta pengawasan terhadap peserta didik dalam saat kegiatan belajar mengajar. (Putria et al., 2020).

Telah dilakukan analisis terhadap pelaksanaan pembelajaran online dalam masa pandemi covid-19 ditinjau dari sudut pandang pendidik. Persepsi pendidik selaras dengan yang disampaikan beberapa peneliti lain yakni keterbatasan sarana prasarana, akses internet yang tidak merata pada masing-masing tempat, fasilitas yang dimiliki peserta didik tidak merata (tidak semua memiliki handphone), orang tua sibuk bekerja. Hal berbeda yang disampaikan dalam penelitian ini yakni dalam mengantisipasi beberapa kendala pelaksanaan pembelajaran online dapat diterapkan bahwa pengalihfungsian dana alokasi media pembelajaran dikelas menjadi online, hal ini dapat menjadi salah satu bentuk dukungan pihak Sekolah dalam mencapai kesuksesan tujuan pembelajaran. Pendidik harus mampu beradaptasi terhadap pembelajaran berbasis teknologi, sedangkan lingkungan belajar lain seperti pihak sekolah, keluarga (orang tua) ikut memberikan andil dalam tercapainya tujuan pembelajaran jarak jauh yang membutuhkan kerja sama berbagai pihak.

Adapun keterbatasan temuan dalam penelitian ini yakni menganalisis persepsi dari pihak sekolah, peserta didik, serta orang tua sehingga kedepannya perlu dilaksanakan kajian lebih lanjut dengan mengkombinasi keempat persepsi tersebut dengan tujuan persepsi dari berbagai sudut pandang yang dapat memaksimalkan hasil sebagai bahan evaluasi dalam pelaksanaan pembelajaran online dalam masa pandemi Covid-19 maupun masa yang akan datang.

\section{KESIMPULAN}

Simpulan pada penelitian ini yakni pembelajaran online dapat dilaksanakan dalam masa pandemi covid19, namun memiliki beberapa kelebihan dan kekurangan. Adapun kelebihan baiknya terus dipertahankan bahkan ditingkatkan sedangkan kekurangan dapat diatasi serta diantisipasi. Beberapa hal dapat dilakukan untuk mempersiapkan pelaksanaan pembelajaran online dengan baik, antara lain: pelatihan penggunaan beragam media pembelajaran online baik bagi guru maupun siswa, pemberian subsidi kouta dengan mempertimbangkan faktor ekonomi, domisili peserta didik, dukungan orang tua dalam memberikan fasilitas belajar siswa saat di rumah, pengalihfungsian dana alokasi media pembelajaran dikelas menjadi online.

\section{UCAPAN TERIMA KASIH}

Penulis menyampaikan ucapan terima kasih pada Akademi Maritim Nusantara Cilacap yang telah mendukung dalam bentuk sarana serta prasarana pada kajian ini, ucapan terima kasih juga diberikan kepada guru Sekolah Menengah Kejuruan Bina Bhakti Cilacap yang telah menjadi subjek pada kajian ini.

\section{DAFTAR PUSTAKA}

Aini, Y. I. (2019). Pemanfaatan Media Pembelajaran Quizizz Untuk Pembelajaran Jenjang Pendidikan Dasar Dan Menengah Di Bengkulu. Jurnal Kependidikan, 2(25), 1-6.

Arnesti, N., \& Hamid, A. (2015). Penggunaan Media Pembelajaran Online - Offline Dan Komunikasi Interpersonal Terhadap Hasil Belajar Bahasa Inggris. Jurnal Teknologi Informasi \& Komunikasi Dalam Pendidikan, 2(1), 85-99. https://doi.org/10.24114/jtikp.v2i1.3284

Chrismawati, M., Septiana, I., \& Dwi Purbiyanti, E. (2021). Peningkatan Hasil Belajar Melalui Model Flipped Classroom Berbantuan Media Power Point dan Audio Visual di Sekolah Dasar. EDUKATIF: JURNAL ILMU PENDIDIKAN, 3(5), 1928-1934.

Damayanthi, A. (2020). Efektivitas Pembelajaran Daring di Masa Pandemi Covid 19 pada Perguruan Tinggi Keagamaan Katolik. Edutech, 19(3), 189-210.

http://sosial.unmermadiun.ac.id/index.php/sosial/article/view/61 
2593 Analisis Pelaksanaan Pembelajaran Online dalam Masa Pandemi Covid-19 berdasarkan Persepsi Guru Sekolah Menengah Kejuruan - Lusiani

DOI: https://doi.org/10.31004/edukatif.v3i5.920

Firdaus, F. (2020). Implementasi Dan Hambatan Pada Pembelajaran Daring Di Masa Pandemi Covid 19. Utile: Jurnal Kependidikan, 6(2), 220-225. https://doi.org/10.37150/jut.v6i2.1009

Handayani, S., Masfuah, S., Kironoratri, L., \& Kudus, U. M. (2021). Analisis Kemampuan Komunikasi Siswa dalam Pembelajaran Daring Siswa Sekolah Dasar. EDUKATIF: JURNAL ILMU PENDIDIKAN, 3(5), 2240-2246.

Herliandry, L. D., Nurhasanah, N., Suban, M. E., \& Kuswanto, H. (2020). Pembelajaran Pada Masa Pandemi Covid-19. JTP - Jurnal Teknologi Pendidikan, 22(1), 65-70. https://doi.org/10.21009/jtp.v22i1.15286

Lindawati, Y. I., \& Rahman, C. A. (2020). Adaptasi Guru Dalam Implementasi Pembelajaran Daring Di Era Pandemi Covid-19. Prosiding Seminar Nasional Pendidikan FKIP, 3(1), 60-67. http://www.tjyybjb.ac.cn/CN/article/downloadArticleFile.do?attachType=PDF\&id=9987

Mardijono. (2008). Persepsi dan partisipasi nelayan terhadap pengelolaan kawasan konservasi laut kota batam. 146.

Mulyadi, E. (2020). Pembelajaran Daring Fisika Melalui Whatsapp , Google Form , Dan Email Dalam Capaian Presensi Aktif Dan Online Physics Learning Via Whatsapp, Google Form, and Email in the Achievement of Active Presence and. Jurnal Karya Ilmiah Guru, 5(1), 34-41.

Mustakim. (2020). Efektivitas Pembelajaran Daring Menggunakan Media Online Selama Pandemi Covid-19 Pada Mata Pelajaran Matematika the Effectiveness of E-Learning Using Online Media During the Covid-19 Pandemic in Mathematics. Al Asma: Journal of Islamic Education, 2(1), 1-12.

Napsawati, N. (2020). Analisis Situasi Pembelajaran Ipa Fisika Dengan Metode Daring Di Tengah Wabah Covid-19. Karst : JURNAL PENDIDIKAN FISIKA DAN TERAPANNYA, 3(1), 96-102. https://doi.org/10.46918/karst.v3i1.546

Putria, H., Maula, L. H., \& Uswatun, D. A. (2020). Analisis Proses Pembelajaran dalam Jaringan (DARING) Masa Pandemi Covid- 19 Pada Guru Sekolah Dasar. Jurnal Basicedu, 4(4), 861-870. https://doi.org/10.31004/basicedu.v4i4.460

Sadikin, A., \& Hamidah, A. (2020). Pembelajaran Daring di Tengah Wabah Covid-19. BIODIK: Jurnal Ilmiah Pendidikan Biologi, 6(2), 214-224. https://doi.org/10.22437/bio.v6i2.9759

Wibawa, R. P., Astuti, R. I., \& Pangestu, B. A. (2019). Smartphone-Based Application "quizizz" as a Learning Media. Dinamika Pendidikan, 14(2), 244-253. https://doi.org/10.15294/dp.v14i2.23359 